\section{Strategic arms meeting}

\section{The need for general discussion on control} agreements.

As the year wears on, the prospect fades that there may be a high-level meeting between the Soviet Union and the United States before 1987 is here, which will be a great misfortune. Virtually the only tangible agreement at Geneva a year ago was that President Reagan and Mr Gorbachov would meet again about now in Washington. Mr Reagan seems to want a meeting, even a meeting at which nothing is decided, but also seems prepared to let the matter slide. Mr Gorbachov, on the other hand, seems to take the view that a meeting not preceded by an agreement on what will be agreed is not worth having. Because Mr Gorbachov has spent much of the time since the Geneva summit producing a string of proposals for agreements on the limitation of strategic arms, without much response from the United States, his position on a second summit must certainly command sympathy. But that does not necessarily imply that it is correct.

Even a meeting without an agreement would be more than merely symbolic. Although it is mutually agreed that the general area of discussion is that of strategic arms control, neither side has a clear idea of what should be the objectives of serious negotiations in the changed circumstances following a decadelong dearth of treaty-signing ceremonies. Not that Soviet ambitions are a secret. Mr Gorbachov wants a test-ban (and is keeping unilaterally to a moratorium on nuclear tests), the abandonment of the Strategic Defense Initiative (but more recently he has said that laboratory rescarch would be tolerable) and has put forward a variety of plans for reducing the numbers of strategic missiles below the limits specified by the Salt II treaty. Mr Reagan appears not to want anything passionately (although the test-ban and the abandonment of SDI are beyond the pale). The negotiations at Geneva seem nevertheless to have reached the point at which the two sides are not far apart in talking of reducing the numbers of strategic warheads by roughly 25 per cent.

So why not sign such an agreement and call a celebration? Because such an agreement would mean nothing without a framework of more general understanding about the problems occasioned by the existence of huge stocks of nuclear weapons. Put simply, a ban on nuclear tests would not, by itself, reduce the chance of mutual annihilation; there would still be plenty of workable weapons in the stockpiles. Nor would an agreement to work within a more restricted formula like Salt II, at least if the reductions were only of the order of 25 per cent. Moreover, there is also something in the arguments of those, called hawks, who say that substantial reductions of strategic arms would be dangerous by weakening the feat that attack would bring swift retaliation.

To the extent that SDI could upset the present balance, giving one side the fear that the other could launch an attack with impunity, the case for regulating that can of worms by mutual agreement is far stronger, perhaps on the basis of a reaffirmation of the Anti-Ballistic Missile Treaty pending renegotiation when the research phase of the programme is complete and the Sovict Union has been made privy to the outcome (as President Reagan has promised). But long before then, the technological basis of nuclear warfare will probably have changed yet again.

That is why strategic arms control agreements between the United States and the Soviet Union are not ends in themselves, but means to other ends. Both governments have a mutual need to get somewhere by 1995 , when the Non-Proliferation Treaty has to be reaffirmed by its signatories, but that is still a distant agenda. The more immediate consideration is that arms control agreements could pave the way to a better political relationship between the two superpowers (as well as allowing third parties to sleep more easily at night). So why not put the cart before the horse, and arrange a summit meeting to talk about the ways in which the superpowers would soften their attitudes towards each other in the event that some kind of agreement is eventually reached? Then the whole process would be easier.

\section{Wall Street jitters}

Last week's slump does not presage another Great Crash, but the need to get rid of US deficits.

THose who knowingly skate on thin ice are a nervous lot. That is the simplest and most comforting explanation of the dramatic collapse of the New York stock markets at the end of last week. Last Thursday, the average value of stocks fell by 4.6 per cent. For the week as a whole. the fall amounted to 7.4 per cent (by the yardstick of the index known as the Dow Jones industrial average). Historically minded stockbrokers' men have been sickened to discover that, apart from a bleak day in May, 1962, there had not been a day when US stock prices declined as fast as last Thursday since 28 October, 1929, part of the prelude to the Great Crash that preceeded the Great Depression.

The same people have also been ready with explanations of why the sombre parallel is not applicable. Now, they say, the markets are computerized to such a degree that, without human intervention, huge quantities of stock are off-loaded whenever there are a few pennies to be made by selling now and using the proceeds to make future purchases of the same, or similar, bits of paper. But that could account for the volume of sales (Thursday's temporary record was beaten on Friday) but not for the slump in stock prices. Another popular explanation is that the markets had been fed with rumours of impending economic indicators suggesting that both the rate of inflation and of economic growth in the United States were increasing, which would imply no further reduction of interest rates; the explanation would have been more convincing if the markets had turned round on Friday, when the rumours were proved false.

The truth is to be found elsewhere, well away from Wall Street, the financial centre in New York. By any standards, this is a curious time in the economic history of the United States. Both the federal deficit (the difference between the government's income and spending) and the country's trade deficit (the cost of imports less that of exports) are higher than they have ever been. The first gap is bridged by borrowing from US citizens the moncy that would, in other circumstances and under different administrations, be raised by increased taxes, the second by the flow of money from abroad, previously from the oil-producing states but now chiefly from West Germany and Japan. The upshot is that US citizens are being given increasing claims on future government revenues (which people will need if they are to enjoy their retirement in the conventional style) while increasing chunks of US commercial and industrial assets are owned from overseas.

On its present scale, this symbiotic relationship could continue indefinitely, provided that the US economy remains productive, but it is hard to see how the system can remain stable if the deficits persist, especially as the signs multiply that deflation continues, making more plausible cvery day the assumption that the Congress will shrink from taking the Gramm-Rudman axe to the budget deficit for the financial year beginning at the end of the month. Is it even possible that the still-hidden trigger for Wall Street's decline last week was merely that the return of the Congress from its brief vacation reminded Wall Street that nothing much would change in an election year?

None of this implies that the United States (or the rest of us) are in 1929 again; the stock markets will no doubt partly recover the losses they have sustained. What this warning crack of the thin ice means is that it is not possible to postpone indefinitely the inevitable adjustment there will have to be between present expectations of prosperity in the United States and the lesser capacity of the economic system to satisfy them. 